\title{
$110 \mathrm{~m}$ 口径全可动射电望远镜专辑·编者按
}

射电天文学诞生并发展于 20 世纪30年代初, 为人类认识宇宙打开了一个全新的探测窗口. 二次世界大战后, 军用雷达被广泛用于民用天文观测, 同时, 一大批专用于天文研究的射电望远镜也相继建成和运行, 使射电天 文进入蓬勃发展的黄金期, 直接促成了 60 年代的现代天文学“四大发现”一—类星体、脉冲星、星际分子、宇 宙微波背景辐射,使得射电天文成为现代天文学最活跃、最前沿的分支.

我国射电天文研究起步于新中国成立以后. 早期首先建设了一批观测太阳的小型射电设备, 20 世纪 80 年代 建成我国的米波综合孔径望远镜, 之后陆续建成了一些投资千万元左右的中型设备. 这些设备在巡视与监测方 面都做出了国际水平的成果, 为我国射电天文的科学研究、技术储备、人才培养做出了重要贡献.

21 世纪以来, 我国天文步入发展快车道, 一批新的大、中型射电观测设备或建成投入使用或在筹划中, 同 时也在积极参与和推动一批更大型的国际合作项目. 就整体而言, 我国在科学研究、人才储备和观测设备建设 方面与欧美差距日趋缩小, 个别领域逐步由跟踪到具备领先优势.

当前, 天文学在黑洞、暗物质暗能量、宇宙与生命起源等方面正孕育着重大突破,而引力波观测窗口刚刚 打开. 引力波天文学已拉开序幕, 步入高灵敏度、大样本时代的射电天文学迫切需要建造更大接收面积、更高 分辨率、更大天空覆盖的射电望远镜, 以探测更暗弱的天体, 获取更早、更多的宇宙信息.

开创性的天文研究要求看得更远、更清楚, 解决方式通常有两种: 一是发展更大口径的单台望远镜, 二是 发展由多个小口径望远镜组成的射电望远镜阵列. 两个方式各有优劣, 例如, 阵列望远镜可以采用成本相对较 低的小口径天线, 增大阵列规模就可以提高接收面积和视场, 但是大规模阵列的造价会急剧上升, 并且阵列的 集群控制、信号处理技术都有待提高, 例如对SKA数据的即时处理就依赖于未来的计算机处理速度; 单口径射 电望远镜则具有观测方式简单灵活的优势, 但是大口径天线同时也面临结构复杂、指向控制精度要求高等诸 多技术挑战. 需要指出的是, 受限于馈源接收带宽, 射电波段往往需要根据科学目标, 分别研制米波、厘米波、 毫米波甚至太赫兹波段的望远镜.

为了展示我国高精度大口径全可动射电望远镜的近期成果, 使科学目标与望远镜设计更紧密地结合, 特别 组织了 $110 \mathrm{~m}$ 口径全可动射电望远镜专辑, 由 12 篇涉及关键技术、重大科学问题的综述和研究论文组成. 其中着 重介绍了在大型反射面天线结构轻量化、快速面型精度检测与主动面补偿、超宽带接收机研制、高速数字终 端、高精度伺服控制、电磁兼容设计等方面的关键技术和突破方案, 分析了其在引力波探测、恒星形成等科学 目标领域的巨大优势和对于推动深空探测与时空基准技术创新的特别意义. 由于篇幅限制和组稿时间仓促, 这 些论文仅呈现了我国对大口径全可动射电望远镜科学和关键技术研究进展的一小部分. 希望通过本专辑的出 版, 吸引更多的工程技术人员关注和投身于 $110 \mathrm{~m}$ 口径全可动射电望远镜项目建设, 为我国天文事业做出贡献.

特别感谢科技部“国家重点基础研究发展计划”项目(2015CB857100)的支持, 感谢专辑论文各位作者的贡 献, 感谢 $110 \mathrm{~m}$ 口径全可动射电望远镜项目团队 10 年来的艰苦奋斗和国内外天文界的支持.

中国科学院新疆天文台

引用格式: 王娜. $110 \mathrm{~m}$ 口径全可动射电望远镜专辑·编者按. 中国科学: 物理学力学 天文学, 2017, 47: 059501

Wang N. Special issue on steerable 110-m aperture radio telescope (in Chinese). Sci Sin-Phys Mech Astron, 2017, 47: 059501, doi: 10.1360/SSPMA2017-00082 